\title{
„OSOBA I CZYN“ A WYCHOWANIE W RODZINIE
}

\author{
WSTĘP
}

W dobie, kiedy mówi się i podkreśla, a także dąży do realizacji zasad humanizmu w różnych dziedzinach życia, w pracy, w stosunkach między ludźmi, wychowaniu - szczególnie ważne staje się dogłębne poznanie człowieka. Tendencjom tym wychodzi naprzeciw książka Osoba $i$ czyn.

Istotnym bowiem jej przedmiotem jest eksplikacja osoby poprzez eksplikację czynu człowieka. W nim bowiem ujawnia się jej istota. Obok przedstawienia istoty, w książce zostaje wyjaśniona jej struktura, relacja natury człowieka do osoby, problemy integracji osoby w czynie.

Wyjaśnienie, kim jest człowiek ma specjalne jednak znaczenie dla wychowania, tym bardziej, że współcześnie brak w nim poprawnego rozpoznania $w$ tym zakresie. Potwierdzają to między innymi teoretyczne próby ujęcia istoty procesu wychowawczego. Dla przykładu zatrzymajmy się przy niektórych z nich.

Mamy na myśli tutaj ujęcie H. Muszyńskiego ${ }^{1}$, J. Reykowskiego ${ }^{2}$, A. Guryckiej ${ }^{3}$, M. Krawczyka ${ }^{4}$, Z. Zaborowskiego ${ }^{5}$, R. Miller ${ }^{6}$. Zacytowani autorzy sprowadzają proces wychowania człowieka do kształtowania osobowości $\mathrm{w}$ znaczeniu ogólnym, lub w kategoriach określonego

1 H. Muszyński, Szkic metodologiczny badań nad wychowaniem, w: Metodologiczne problemy pedagogiki, Red. Muszyński, Wrocław 1967.

2 J. Reykowski, Osobowość a wychowanie, w: Metodologiczne problemy pedagogiki.

3 A. Gurycka, Ocena skuteczności oddziatywań wychowawczych - istotny problem psychologicznych podstaw wychowania, „Psychologia Wychowawcza”, 1969, nr 1 .

4 M. Krawczyk, Model wychowania, „Ruch Pedagogiczny”, 1967, nr 3.

$5 \mathrm{Z}$. Zaborowski, O integralne ujęcie procesu wychowawczego, „Kwartalnik Pedagogiczny", 1967, nr 1.

6 R. Miller, Proces wychowania $i$ jego wyniki, Warszawa 1966. 
ideału, odpowiadającego przyjętej ideologii. W wypadku przyjmowania, jako celu wychowania, kształtowania osobowości, traktuje się je jako zastosowanie odpowiednich praw rozwoju psychiki oraz organizmu. Rozumienie celów wychowania zostaje ograniczone do widzenia człowieka w kategoriach somato-psychicznych. W praktyce oznacza to dążenie do pełnego rozwoju możliwości psychicznych i somatycznych, do zrealizowania dojrzałej osobowości w znaczeniu psychologicznym. Całość zaś wychowania zostaje sprowadzona do zapewnienia warunków dla realizacji norm rozwojowych $\mathrm{w}$ poszczególnych okresach. Takie rozumienie wychowania, jak widzimy, sprowadza człowieka do dostępnych metodom behawioryzmu zachowań się i pomija jego istotę, której na imię osoba. Jest to zatem wychowanie ograniczone, niepełne, zwrócone do „części” człowieka, a więc i nie w pełni humanistyczne.

W przypadku drugim, tzn. kształtowania człowieka według przyjętego ideału, mamy do czynienia $z$ urabianiem, nadawaniem określonego kształtu poszczególnym cechom psychicznym i somatycznym człowieka. Jest to zatem wychowanie pomijające właściwie człowieka, a przede wszystkim podporządkowujące go określonemu ideałowi. Nadawanie odpowiednich cech poszczególnym strukturom człowieka, to podobnie jak w poprzednim ujęciu, zwrócenie się do „fragmentu” człowieka.

Istniejąca zatem sytuacja na terenie teorii wychowania, przy jednoczesnym dążeniu do realizacji humanizmu, wskazuje na występowanie $\mathrm{w}$ niej braku obiektywnego rozumienia człowieka. Wynika to z nieznajomości pełnej koncepcji człowieka. Stąd książka Osoba i czyn stanowi wypełnienie luki, jaka powstała $\mathrm{w}$ tym zakresie.

Wymienieni wyżej autorzy rozpatrując strukturę procesu wychowawczego wskazują, że istotne miejsce $\mathrm{w}$ nim zajmuje rodzina. Przyznając jej taką pozycję jednocześnie podkreślają, że odbywające się w niej wychowanie jest procesem niezamierzonym, nieświadomym i niezorganizowanym. Używane określenia wyraźnie obniżają wartość oddziaływań wychowawczych rodziny. Argumenty uzasadniające powyższe stwierdzenia, nie wynikają jak dotąd $z$ systematycznie przeprowadzonej konfrontacji programu wychowania $\mathrm{z}$ możliwościami rodziny $\mathrm{w}$ tym zakresie. Stanowią one co najwyżej monograficzne przyczynki do tego zagadnienia, stąd trudno uznać je za wystarczające.

Zarysowana w Osobie i czynie koncepcja człowieka stanowi okazję do sformułowania programu - wprawdzie ogólnego - pełnego wychowania człowieka oraz do konfrontacji znaczenia rodziny w realizacji tego programu 7. I tym też zagadnieniem zajmiemy się w niniejszym artykule.

7 Por. Cz. Czapów, Rodzina a wychowanie, Warszawa 1968; M. Ziemska, Podstawy rodzicielskie, Warszawa 1972. 


\section{PROGRAM WYCHOWANIA OSOBY}

Każdy program wychowania określa swój cel, a następnie precyzuje wiodące do niego kolejno zadania. W moim zrozumieniu książki punktem docelowym programu wychowania powinien być człowiek, który spełnia siebie w czynie. Przy tym termin ,,spełnia”, jak pisze Autor, oznacza „urzeczywistnia, niejako doprowadza do właściwej pełni tę strukturę, która jest dla niego znamienna $\mathrm{z}$ racji osobowości, $\mathrm{z}$ tej racji, że jest kimś, a nie tylko czymś". Czym więc charakteryzuje się pełna struktura człowieka jako osoby? Jaka ona jest?

Znamionuje ją przede wszystkim to, że jest świadoma siebie, świadoma tego, że działa i to działa świadomie. Dokonuje się to dzięki samowiedzy, która obiektywizuje stany świadomości i wypełnia świadomość treściami znaczeniowymi. Samowiedza formuje samoświadomość. Warto zwrócić uwage na fakt, że samowiedza kształtuje się jako rezultat samodoświadczenia, ale także korzysta z wiedzy ogólnej o człowieku. Cechą świadomości jest jej reflektywność, która pozwala na przeżycie siebie, swoich czynów, jako należących do podmiotu, jakim jest nasze ,,ja”. $\mathrm{W}$ ten sposób czyn staje się rzeczywistością podmiotową w człowieku. Podmiotowe przeżycie czynów może być zakłócone przez emocjonalizację świadomości, co jest następstwem tego, że człowiek przeżywając siebie przeżywa także swoje ciało, które odbija się w świadomości. W tej sytuacji ważną rolę do spełnienia ma samowiedza, która obiektywizuje emocje i uczucia. Stąd istotnym zadaniem wychowania jest właściwe usprawnienie samowiedzy, która potrafi zapanować nad czuciami.

Człowiek uświadamiając sobie siebie stwierdza w sobie istnienie dwóch zasadniczych kierunków dynamizmu. Można je określić jako ,,człowiek działa” oraz „,coś się dzieje w człowieku”. Znamiennym dynamizmem dla osoby jest dynamizm, który określamy jako „,człowiek działa”, w którym on kryje się jako sprawca. Obok tego dynamizmu istnieje w człowieku ten drugi, który określamy jako ,,coś się dzieje w człowieku'. Jest on znamienny dla tego, co określamy jako naturę człowieka. Osoba jest ściśle związana z naturą.

Różny jest stosunek świadomości, jej reflektywności do wymienionych rodzajów dynamizmów w człowiek̄u. Człowiek posiada świadomość swego ciała, ale już nie uświadamia sobie poszczególnych faktów dynamicznych składających się na dynamizm wegetatywny. Natomiast dynamizm psycho-emotywny posiada odbicie i przeżycie w świadomości. Należy również wyróżnić występowanie podświadomości, którą trzeba zobiektywizować, czyli nasycić treściami znaczeniowymi, pochodzącymi z samowiedzy. Wspólnym ogólnym rysem dynamizmów w człowieku jest to, 
że łączą się ze stawaniem się. Postać owego stawania się bywa różna w zależności od dynamizmu którego dotyczy.

Analizując działanie człowieka, jego czyn, owo stawanie się, trafiamy na moment wolności, jako podstawowy dla niego. W nim też zakorzeniona jest wolność nadająca wartość moralną czynom. Wolność człowieka nie ogranicza się do samego chcę - nie chcę, ale jest samostanowieniem. Samostanowienie jest następstwem tego, że osoba posiada siebie, jak również i tego, że jest posiadana tylko i wyłącznie przez siebie. Wolność człowieka polega na tym, że dynamizowanie swego podmiotu uzależnione jest od siebie. Do tego konieczne jest bycie konkretnym ,,ja”, które samo dla siebie jest przedmiotem. Takiej sytuacji nie stwierdzamy na poziomie samej natury. Wola w osobie pełni także funkcję władzy i pozwala na rozstrzyganie. Ograniczana w tym bywa, lub inaczej - natrafia na utrudnienia ze strony potencjalności ciała. Stąd powstaje napięcie między wolą, jako władzą samostanowienia, a potencjalnością ciała, emotywnością i popędowością, co stanowi szczególnie ważny problem dla wychowania.

Zajmijmy się jeszcze bliższą charakterystyką woli, która decyduje o transcedencji osoby $\mathrm{w}$ czynie. Istotnym momentem dla aktu woli jest rozstrzyganie. Poprzez rozstrzyganie osoba wychodzi ku dobru, odpowiada na dobro, wartość. Rozstrzyganie dokonuje się poprzez poznanie prawdy o dobru i jej przyporządkowanie. Ujmując zagadnienie dokładniej trzeba stwierdzić, że rozstrzyganie uwarunkowane jest sądem o wartości. Zadaniem więc wychowania jest ukształtowanie odpowiednich sprawności w poznawaniu wyżej wymienionych wartości oraz nabycie sprawności w sądach.

Dzięki samostanowieniu człowiek spełnia czyn, co oznacza równocześnie, że spełnia w czynie siebie, czyli się urzeczywistnia. Urzeczywistnienie siebie oznacza stawanie się dobrym lub złym. Nie zawsze tak jednak bywa, zależy to bowiem od woli, która może być dobrze lub źle użyta. Kontrolę nad wolą pełni sumienie, ono bowiem określa prawdziwe dobro w czynie i stwarza powinność, będącą zależnością od prawdy. W ten sposób powstaje wewnątrz osoby rzeczywistość normatywna, która formułuje normy i oddziałuje nimi na czyny ludzkie. Odpowiadanie na wartości rodzi odpowiedzialność. Kolejnym więc zadaniem wychowania będzie pomoc w ukształtowaniu wewnątrz osoby rzeczywistości normatywnej i wszystkich jej atrybutów.

Przedmiotem dotychczasowej charakterystyki była osoba ludzka. Wydobyta została jej specyficzna dynamika, która nie znamionuje jednak natury człowieka. Stąd powstaje problem integracji osoby w czynie, jako istotny punkt programu wychowawczego.

Cechą specyficzną bowiem dynamizmu ciała człowieka jest jego reak- 
tywność. Konsekwencją reaktywności jest „dzianie się” w człowieku. Oczywiście, osoba dzięki posiadaniu ciała ma możność panowania owej reaktywności. W rezultacie ciało nabiera sprawności, do czego należy dążyć w wychowaniu.

Mówiąc o naturze nie sposób pominąć zagadnienia popędów, które stanowią dynamiczną orientację natury w określonym kierunku. Znaczenie ich w osobie polega na obiektywnej wartości celów, ku którym człowiek zostaje przez nie skierowany, a które należy poznać.

Obok ciała należy rozważyć także psychikę, na którą składają się „, te pierwiastki człowieczeństwa oraz każdego konkretnego człowieka, które w doświadczeniu człowieka odkrywamy jako w pewien sposób spójne, zintegrowane z cia$ł$ e m, a [...] nie będące - same w sobie - tym ciałe m" (s. 238). Rysem znamiennym psychiki jest jej emotywność, która jest wrażliwa na wartości. Przejawia się ona między innymi przy pomocy czucia, które pozwala na uświadomienie własnego ciała. Obok czuć cielesnych człowiek czuje siebie w sposób bardziej integralny, tzn. to, co stanowi o własnym ,,ja” i jego dynamice, a także świat. W ten sposób kształtuje się przeżycie własnego ,,ja” w świecie, a także przeżycie świata.

Czucia rozwijają w każdym człowieku jakąś indywidualną jego wrażliwość, która oznacza właściwość czucia i odczuwania, a pełni funkcję poznawczą albo w niej uczestniczy (s. 250). Są one ukierunkowane na wartości. Ta ukierunkowanie nie pozwala jednak na transcedencję osoby w czynie, gdyż brak jest odniesienia do prawdy. Z tego też względu zachodzi potrzeba przeniknięcia wrażliwości prawdziwością. Znaczenie wrażliwości zależy od tego, im prawdziwiej odczuwa ona wszelkie wartości, im lepiej w ich przeżywaniu odzwierciedla się porządek, jaki wśród nich w rzeczywistości zachodzi. Zadaniem więc wychowania jest rozwój bogactwa czuć oraz prześwietlanie wrażliwości prawdą, umożliwianie poznania obiektywnego porządku rzeczywistości.

Obok wrażliwości należy zwrócić uwagę i na inny rys psychiki, a mianowicie na przeżycie podniecenia. Jest ono uczynnieniem o silnej oprawie somatycznej. Obok niego można wskazać także na uniesienia. Wymienione reakcje składają się na całokształt pobudliwości w człowieku, które należy właściwie ukierunkować. Z jednej strony wzbogacają psychikę człowieka, z drugiej jednak mogą stanowić utrudnienie. Obok podnieceń należy wyróżnić w emotywności wzruszenia, które charakteryzuje między innymi to, że ich treści są źródłem uczuć, których bogactwo jest ogromne i wśród których można wyróżnić odmienne ich poziomy.

Emotywność życia psychicznego człowieka jest czymś, co się z nim dzieje, stanowi swoistą sprawczość samorzutną, która nie podlega samostanowieniu. W ten sposób rysuje się napięcie między podmiotowością 
a sprawczością. Stąd problem syntezy podmiotowości i sprawczości. Problem ten tym bardziej się rysuje, że emotywność i wytwarzane przez nią stany nie tylko mają charakter przelotny, ale często utrwalają się w człowieku. Utrwalanie się emotywności prowadzi do wykluczenia samostanowienia. W wychowaniu należy położyć nacisk na ukierunkowanie emotywności.

Przeciwstawiając emotywność sprawczości musimy sobie uświadomić, że jest to także problem wartości, do których jest zwrócona emotywność, a właściwie uczucie. W tym odniesieniu do wartości tkwi zresztą możność integracji. Emotywność bowiem wskazuje na emotywne treści skierowane poza siebie, i to na pewną wartość, stwarza tylko okazję do takiego przeżycia wartości, do jej doświadczalnego poznania. Ostatecznie można stwierdzić, że powoduje ona spontaniczne przeżycie wartości. Napięcie więc między sprawczością a emotywnością powstaje z różnego odniesienia do wartości. Owo napięcie dotyczy nastawienia „ku” dobru lub „,przeciwko” złu. W tym też miejscu ujawnia się szczególne znaczenie sprawności. Jest to dążenie do integracji, bo chodzi o urzeczywistnienie między spontaniczną sprawczością a osobową sprawczością struktury samopanowania i samoposiadania.

Znaczenie sprawności polega na tym, że dążą one do podporządkowania podmiotowości względem sprawczości osoby, przy maksymalnym wykorzystaniu energii emotywnej. Integrujący proces sprawności polega na tym, że wola wspierana poznaniem umysłowym umie przejmować ze spontanicznych emocji - atrakcji i repulsji — to, co prawdziwie jest dobre, a odrzucać to, co prawdziwie jest złe. Warto podkreślić, że jest to proces całego życia, a jednocześnie proces, w którym chodzi o urzeczywistnienie i zarazem ujawnienie jedności na gruncie swoistej złożoności osoby ludzkiej. Człowiek stale musi swoją transcedencję dopełniać integracją.

Istotnym rysem czynu człowieka jest również i to, że jest on spełniany wspólnie $\mathrm{z}$ innymi. W tym przypadku zachodzi korelacja czynu wspólnie $z$ innymi, nosząca na sobie znamię uczestnictwa. Ważnym więc zadaniem jest właściwe „uspołecznienie”.

Można zatem powiedzieć, że punktem docelowym wychowania w znaczeniu ogólnym powinien być człowiek, który działa, postępuje, uczestniczy, a nie zachowuje się, przez fakt tego wszystkiego, co się w nim dzieje, a tym samym spełnia siebie w dobru. Drogą do tego jest osiągnięcie samowiedzy, refleksywności, wejście w posiadanie siebie i samostanowienie. Jest to droga przekroczenia niejako natury ludzkiej na rzecz osoby człowieka, lub inaczej: proces integracji człowieka. Wskazane zadania, a także droga ich realizacji nie mogą jednak pomijać tego wszystkiego, co zostało ujęte $\mathrm{w}$ prawach psycho-somatycznego funkcjo- 
nowania oraz kształtowania natury człowieka. Więcej, właśnie w nich odkrywamy możliwości bycia osobą oraz warunki, jakie muszą wystąpić, aby człowiek spełnił siebie. Szczególnym miejscem potrzebnych warunków dla rozwoju osoby jest właśnie rodzina.

\section{MOŻLIWOŚCI WYCHOWAWCZE RODZINY}

Problemy wychowania w rodzinie stanowią przedmiot zainteresowań wielu dyscyplin naukowych. Stąd niewątpliwie bogata literatura. Brak w niej jednak teorii wychowania w rodzinie, co najwyżej wskazuje się na istnienie pewnych prawidłowości w tym zakresie. Uwagi więc poniższe należy potraktować jako pewną próbę wstępu do rozważenia teoretycznych podstaw możliwości wychowawczych rodziny. Źródłem staną się dotychczasowe prace dotyczące rodziny, wychowania i rozwoju człowieka w niej, z zakresu socjologii, psychologii i pedagogiki ${ }^{8}$.

Stan wiedzy w wymienionych naukach pozwala na wysunięcie następujących hipotez odnośnie możliwości rodziny w zapewnieniu człowiekowi spełnienia siebie jako osoby. Oto one:

$1^{\circ}$ - rodzina uruchamia możliwości stawania się osobą;

$2^{\circ}$ - rodzina tworzy podstawowe elementy strukturalne osoby;

$3^{\circ}$ - rodzina determinuje kierunek spełniania siebie jako osoby.

Przejdźmy do kolejnego wyjaśnienia podstawowych hipotez.

W momencie urodzenia dziecko nie jest świadome siebie ani też otaczającej rzeczywistości. Wyposażone w możliwości reagowania w sensie odbierania bodźców, oczekuje na odpowiednie stymulacje, które są warunkiem dalszego rozwoju. Zdaniem A. Gesella właśnie rodzina zapewnia konieczne osobowe stosunki dostarczające właściwych stymulacji ${ }^{9}$. Według M. Jacuńskiej-Iwińskiej rodzina, w odróżnieniu od domu dziecka, dostarcza bogatej gamy bodźców ze strony dorosłych ${ }^{10}$. Obok bowiem matki w kontakcie $\mathrm{z}$ dzieckiem są i inne dorosłe osoby: ojciec, dziadkowie, a także rodzeństwo. W ten sposób dziecko dokonuje uświadomienia sobie siebie. Potwierdzeniem znaczenia rodziny są także wszelkie badania osób wychowywanych poza rodziną, wśród których bardzo wyraźnie wy-

8 A. Dodziuk-Lityńska, D. Markowska, Rodzina $w$ miastach polskich. Przegląd badań społecznych $z$ lat 1945-1968, Wrocław 1971.

9 A. Gesell, F. L. Ilg, Le jeune enfant dans la civilisation moderne, Paris 1953.

10 M. Jacuńska-Iwińska, Reakcje dorosłych na aktywność małego dziecka jako czynnik różnicujacy środowisko domowe i zakładowe, „Psychologia Wychowawcza”, 1963, nr 5; Tejże, Ukierunkowanie jako wskaźnik aktualnego oraz czynnik dalszego rozwoju małego dziecka, „Psychologia Wychowawcza”, 1965, nr 1; Tejże, Zależność pomiędzy aktywnościa małego dziecka a rodzajem reakcji dorostych na tę aktywność, „Psychologia Wychowawcza”, 1966, nr 5. 
stępują zaburzenia w rozwoju świadomości tego kim są, procesy dezintegracji osoby ${ }^{11}$.

Rodzina decyduje także o możliwościach nabycia odpowiedniej wiedzy i samowiedzy. Drogą do tego jest rozwój mowy i myślenia.

Rozwój mowy rozpoczyna się na długo przed właściwym posługiwaniem się językiem. Jest to okres przedsłownego porozumiewania się. Wyraża się ono w ujawnianiu przez dziecko szeregu sygnałów - informacji w postaci najpierw krzyku. Innym sygnałem mowy przedsłownej jest uśmiech, początkowo wyrażający się ożywieniem wyrazu twarzy, odkrywany zwykle tylko przez najbliższe dziecku osoby. Nieco później zjawia się wyraźny uśmiech kierowany do osoby, a następnie pierwsze samogłoski, pierwsze „rozmowy”. Dziecko przez te sygnały uczy się wzywać partnerów, domagać się zaspokojenia swoich potrzeb. Do tego okresu należy porozumienie działaniowe, czyli działanie zrozumiałe dla osoby, która je obserwuje. Dla wymienionego więc okresu rozwoju mowy szczególnie ważna jest obecność osób, które będą odczytywały we właściwy sposób sygnały nadawane przez dziecko, dzięki odpowiedniemu na nie reagowaniu. W ten sposób dokona się proces nadawania znaczenia owym sygnałom, a następnie ich różnicowania. Obecność tych osób powinna być stała, a także zaangażowana. Ważne jest również, aby dorośli nie tylko reagowali, ale przemawiali i działali przy i wokół dziecka. Przedstawioną sytuację modelową znajdziemy właśnie w rodzinie. Potwierdzają to cytowane już tylokrotnie badania M. Jacuńskiej-Iwińskiej. I tak np. w odniesieniu do domu rodzinnego autorka zarejestrowała 321 razy uśmiech dziecka, w zakładzie natomiast 111 razy. Krzyk natomiast wystąpił w domu 250 razy, u dzieci zakładowych zaś 624 razy. Szczególnie jednak charakterystyczną cechą sytuacji życia rodzinnego było występowanie tzw. przygrywki przed płaczem, która miała miejsce aż 347 razy i była częstsza niż krzyk (260 razy) ${ }^{12}$. Zjawisko to potwierdza także J. Piaget ${ }^{13}$. Znaczenie więc rodziny jest ogromne.

Po okresie porozumienia przedsłownego przychodzi okres właściwej mowy. Jej rozwój zależy od powiązania tego, co się mówi, z konkretnymi sytuacjami i to takimi, które dziecko interesują i w których ono działa. Chodzi więc o to, aby pobudzać dziecko do wypowiadania się w momentach kiedy odczuwa jakąś potrzebę osiągnięcia czegoś. Występują one zwykle w momentach aktywności dziecka. Sytuacje takie należy tworzyć przez dostarczanie interesujących wzorów działania do naśladowania. I znowu wskazane elementy konieczne dla rozwoju mowy właściwej znajdujemy $w$ rodzinie.

11 I. Bielicka, H. 0lechnowicz, O chorobie sierocej małego dziecka, „Materiały do nauczania psychologii", Seria IV, t. 2, Warszawa 1966.

12 M. Jacuńska-Iwińska, Ukierunkowanie aktywności, art. cyt.

13 J. Piaget, Narodziny inteligencji dziecka, Warszawa 1966. 
Rozwój zatem mowy, tego warunku kształtowania się pojęć, sądów, wiedzy, samowiedzy znajduje w rodzinie szczególnie dogodne warunki. Ogólnie można więc powiedzieć, że wyrażają się one w osobowych kontaktach, przy okazji powtarzających się, nawet kilkakrotnie w ciągu dnia, codziennych sytuacjach, w atmosferze swobody i wzajemnego zainteresowania. Przygotowywane są przez okres mowy przedsłownej, to znaczy nawiązania kontaktu i porozumienia $z$ człowiekiem. Stworzone przez rodzinę sprzyjające warunki dla rozwoju mowy są wynikiem osobowego charakteru tego środowiska. Następstwem tego jest osobiste, bezpośrednie, indywidualne porozumiewanie się. W dodatku znamionuje je emocjonalne zaangażowanie.

Rodzina zatem uruchamia świadomość siebie, samowiedzę, skierowuje ku prawdzie o rzeczywistości, buduje podstawy do odkrywania prawdy.

Wskazuje się również na niezbędność rodziny w uruchomieniu możliwości „uczestnictwa”, jak je określa Autor Osoby i czynu. Drogą do uczestnictwa jest rozwój emocjonalny i społeczny człowieka. Drogą do tego jest wyróżnienie siebie, drugiego człowieka, nawiązanie więzi z nim i grupą, a dzięki temu przejście do więzi o szerszym zasięgu. O pierwszych etapach procesu - brania, zabiegania - mówiliśmy wyżej. To również rodzina zapewnia prawidłowe przejście przez fazy rozwoju społecznego i ukształtowanie się podstawowych działań społecznych. Rodzina daje bowiem pojęcie dobra osoby, tego elementu konstytuującego dobro wspólne, zasad życia społecznego. Dzieje się to znowu dzięki temu, że rodzina dostarcza w odpowiednim czasie właściwy rodzaj oraz ilość stymulacji ${ }^{14}$ przez fakt bycia wspólnotą osób. W rezultacie rodzina stwarza podstawy dla życia emocjonalnego, dla działania społecznego.

W odróżnieniu od tego sytuacje wychowawcze w domu dziecka charakteryzuje przede wszystkim brak osób i indywidualnego zajęcia się dziećmi. Kontakty osób dorosłych z dziećmi są pozbawione zaangażowania emocjonalnego. Również zbyt ograniczona ilość przedmiotów w nich występuje. Cechy te powodują ujemne konsekwencje w rozwoju umysłowym, emocjonalnym i społecznym dzieci. Jeśli znajdują się one w domu dziecka od urodzenia, to zachodzi niebezpieczeństwo zamrożenia możliwości rozwojowych człowieka, owego stawania się.

Druga hipoteza mówi o tym, że rodzina tworzy podstawowe elementy strukturalne osoby. Proces rozwoju człowieka jest procesem ciągłym, w którym każda faza życia jest ściśle uzależniona od poprzedniej i warunkuje następującą po niej. Na podstawie więc tego, co poprzednio powiedziano, możemy stwierdzić, że rodzina zapewnia samowiedzę, a następnie przez wiele lat wzbogaca ją wiedzą o człowieku i jego rozlicznych odmianach. Jest to zresztą wiedza podstawowa, stanowiąca punkt

14 T. Kukołowicz, Rodzina w procesie uspołecznienia dziecka, Lublin 1973. 
wyjścia dla możliwości gromadzenia innej, obszerniejszej wiedzy, w rodzinie bowiem występuje bogactwo realizowanych odmian dobra osoby. Rodzina powtarza w swym mikrokosmosie makrokosmos społeczeństwa, które tworzą osoby.

Również rodzina, przez fakt, że stanowi podstawę uspołecznienia człowieka, stwarza strukturę samostanowienia, która jest konieczna dla realizacji uczestnictwa. Jest to także rezultatem działania w niej jako podstawowych zasad życia rodzinnego: miłości, sprawiedliwości oraz władzy. Rodzina domaga się podporządkowania natury osobie, integracji w czynie. W konsekwencji rodzina kształtuje podstawy wolności w człowieku, wyrażającej się w samoposiadaniu i samostanowieniu.

Powstaje oczywiście pytanie, jak uzasadnić ową ,,podstawowość" rodziny $\mathrm{w}$ zapewnieniu spełnienia się osoby? Sięgając do istoty rodziny należy podkreślić, że to, co ją charakteryzuje, to podmiotowość jej życia. Wynika ona zarówno z celu rodziny, jakim jest obdarzanie człowieczeństwem każdego z jej członków, jak również sposobu w jaki rodzina żyje, kontaktuje się $\mathrm{z}$ sobą i realizuje swoje cele ${ }^{16}$.

Podsumowując tę część rozważań należy podkreślić, że tylko rodzina zawiera w sobie niezbędne elementy konieczne dla rozpoczęcia, uruchomienia niejako prawidłowego rozwoju osoby ludzkiej. Między rodziną bowiem jako wspólnotą osób, a stającym się człowiekiem zachodzi ścisła odpowiedniość, co skrótowo pokazano wyżej na przykładzie rozwoju niektórych możliwości człowieka.

Pomimo tych niewątpliwych walorów rodziny rysują się jednak wątpliwości, czy jest ona zdolna w całej pełni zapewnić spełnienie siebie jako osoby?

W tym miejscu nasuwa się spostrzeżenie, że rodzina, mówiąc ogólnie, determinuje kierunek oraz zakres spełniania siebie. Wynika to ze sposobu w jaki rodzina wychowuje. Podstawowym bowiem „czynnikiem” wychowującym są rodzice oraz stopień ich dojrzałości osobowej. Wszelkie niedociągnięcia $\mathrm{w}$ tej dziedzinie powodują ograniczenie możliwości wychowawczych rodziny. Ograniczenia te dotyczą zarówno kierunku (ku dobru czy ku złu), jak również zakresu, w jakim uruchomione są wrażliwości wychowanków, aby spełnić siebie. Dostrzegamy w życiu rodzinnym różne procesy dezintegracji dotyczące osób - rodziców, ich wzajemnych odniesień, stosunku do innych społeczności.

Wskazane ograniczenia w wychowaniu rodzinnym oczywiście nie są jakąś bezwzględną determinacją. Przezwyciężenie ich może się dokonać przez pracę nad sobą oraz współpracę z łaską. Poważną rolę odegrać może również właściwie pomyślana pomoc rodzinie, poradnictwo. Naczel-

15 Tamże, 127.

16 Cytowana praca T. Kukołowicz jest w całości poświęcona temu zagadnieniu. 
nym zaś zadaniem poradnictwa powinna być personalizacja rodziny jako wspólnoty osób.

\section{ZAKOÑCZENIE}

Wskazując na ogromne znaczenie Osoby $i$ czynu dla wychowania we współczesnych czasach, starałam się wykazać, jakie możliwości realizacji zaproponowanego przez książkę programu wychowawczego ma rodzina. W sposób ogólny wskazałam na jej podstawową rolę w tym zakresie. Podstawowość tej roli wyraża się w tym, że proces wychowania poza nią jest skazany na utrudnienia ze strony dezintegracji osoby i to na różnych jej poziomach. Oczywiście, brak teorii życia rodzinnego stanowi poważną przeszkodę w dogłębnej analizie tego zagadnienia. Wydaje się jednak, że zasługuje na podkreślenie to, że niezbędność rodziny w spełnianiu się osoby wynika z faktu bycia przez nią wspólnotą osób, nastawioną na obdarzanie się człowieczeństwem. 